$\xi=-1$

\title{
The influence of E-WOM on purchase intentions in local culinary business sector
}

\author{
Nizar Alam Hamdani ${ }^{1 *}$, Galih Abdul Fatah Maulani², \\ ${ }^{1,2}$ Universitas Garut, Indonesia \\ *Corresponding author E-mail: nizar_hamdani@uniga.ac.id
}

\begin{abstract}
With a large population and high consumer interest in local culinary, Indonesia becomes a potential market for small and medium-sized local culinary enterprises. However, most of local small and medium-sized enterprises (SMEs) in culinary sector face a wide range of challenges especially when it comes to huge promotion costs. Fortunately, the ever-increasing numbers of Internet users in Indonesia provides an opportunity for these SMEs to promote their products through Electronic Word of Mouth (E-WOM). E-WOM can provide solutions for them since it has a quick and wide promotion reach. The purpose of this study is to find out the influencing factors of EWOM on consumers' perceived quality and purchase decisions. This study used a descriptive and verification method. The samples include 76 followers of Instagram accounts of the local culinary enterprises based in Garut, Indonesia chosen using the probability, simple random sampling technique. To find out the influencing factors of E-WOM on the brand image, the data were analyzed using SPSS confirmatory factor analysis. Factors that are formed from the results of the analysis are product information and Emotions. In addition, a PLS method was carried out to explore the influence factors of E-WOM on consumers' purchase intention using SmartPLS software. Based on PLS calculation, it can be concluded that E-WOM has positive influence on purchase intention.
\end{abstract}

Keywords: E-WOM; local culinary; SMEs; purchase intention.

\section{Introduction}

At this time the culinary business gained community and government attention. The number of unique and varied culinary business has changed consumer behavior in consuming culinary. Most of the culinary businesses are managed by SMEs, these businesses are easily run because the raw materials can be directly and easily obtained, bought and sold. Culinary business is a complicated business. Not only marketing but also SMEs' innovation and competence play significant roles in maintaining the sustainability of the business (1).

In the first quarter of 2015, the national culinary industry growth reached $8.16 \%$. It is higher than non-oil industry growth that reached $5.21 \%(2)$. Culinary business in Indonesia is dominated by small and medium-sized enterprises (SMEs) that covers 70 percent of the total culinary business enterpreneurs (3).

Based on Internet Service Provider Association survey result, It was found that the number of interet users in indonesia has approximately reached 132.7 million people with the distribution of 52.5 percent male users and 47.5 percent female users. Untill the end of 2016, most internet users comprising 86.3 percent or 86 million people of the population live in Java Island. In addition, the most visited internet content is online shop by 82.2 million visitors or 62 percent. The most popular social media is Facebook with 54 percent or 71.6 million people visiting the platform and the second in this list is Instagram with 19.9 million users or 15 percent. The characteristics of Internet users, gender and media content significantly determine the success of $\operatorname{E-WOM}(4,5)$. This statement is in line with Lancastre (6) stating that online business can enhance company's competitive ability.

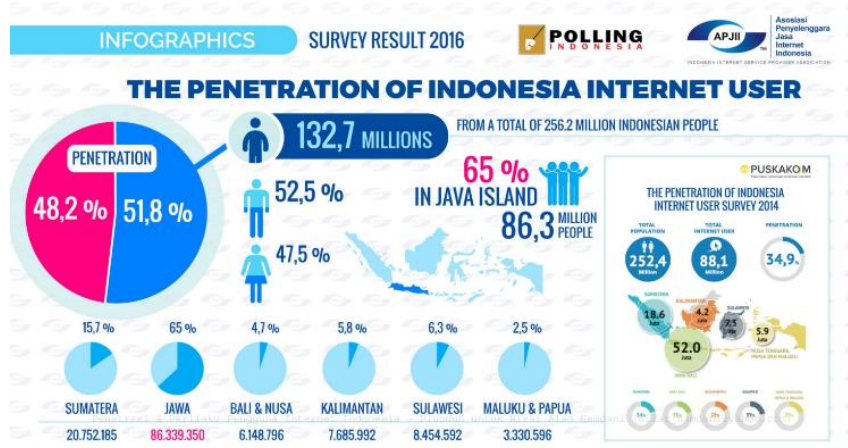

Fig 1: Internet Users in Indonesia in 2016

Local food-based culinary tradition is a form of local wisdom functioning as a description of the community life patterns representing collective identity and socio-cultural representation in conceptualizing food and the food social functions. Garut is also known as Switzerland van Java. That nickname was given as Garut was once a chocolate producer in Java Island. Beside Dodol Garut and Cokelat Garut, Garut Regency is also famous for its various local culinary such as Baso Aci, Burayot, Moring, Opak, Ladu Malangbong, Keripik, Dorokdok, Soto, Cocodot, Bagelen, Kopi Garut, Es Goyobod, Seblak, Endog Lewo and other culinary products widely known and consumed by local residents or visitors.

Trade sector and restaurant, despite being second to agriculture, has a major role in Gross Regional Domestic Product in Garut Regency. The Gross Regional Domestic Product of hotel and restaurant revenue in Garut is approximately Rp. 1.3 trillions (7). 
Word Of Mouth (WOM) may provide product knowledge and information to both individual and group of consumers(8). The current high tech change has offered an opportunity to run culinary business. This has directly affected the whole society in Indonesia. Nowadays, some people ,even middle to low society, are familiar with communication technology like internet as it provides a lot of convenience for its users.

In Electronic Word Of Mouth or E-WOM, the consumer makes either positive or negative comments to the product via the internet. The statements may come from potential customers, actual customers, and former customers (9). With the increase number of internet users every year, companies need the media to market their products through the internet or electronic marketer tool that can be accessed by everyone. Electronic Word Of Mouth or EWOM becomes an easy and appropriate choice to do promotion in a company's business because of its facilities such as website, forum, messenger, and other social media like Facebook, Twitter, Instagram and so on (10). The increasing number of internet and social network users is also essential as WOM is not only done in person but it can also be done in any other forms including internet called electronic word of mouth (e-WOM). e-WOM is more effective than offline WOM because the former has greater accessibility and wider coverage.

Garut culinary is incorporated in Instagram group Jajanan Garut. This group has 60.400 followers and it accomodates 78 SMEs local culinary business. The main problem of the SME local culinary in Garut is the product and service marketing cost. The promotion cost is deemed too expensive for the culinary SMEs. It is in line with Yulianto(11) saying that SME's culinary problem in Garut is market access control in the forms of marketing area and market share. This is due to the lack of technology utilization and development capabilities.

This study aims to explore the factors that make up the electronic word of mouth and examine how EWOM influences perceived quality and purchase decision.

\section{Literature Review}

Word-of-mouth communication is basically a message about a company's product or service, or about the company itself, in the form of comments about product performance,hospotality, honesty, speed of service and other things perceived and experienced by someone that are communicated to people other. The messages conveyed can be either positive or negative depending on what the messagegiver feels for the services he or she accepts.

The change in marketing paradigms has also changed consumer behaviour as traditional marketing has been left out (12). To date, consumers prefer word-of-mouth because it is considered accurate in providing pesonal-experience-based informations. Word-ofmouth communication can significantly affect consumer behavior Bass (13)and (14) and (15) explained that E-WOM greatly affects conumer buying decision. Lamba and Manav Aggrawa(16) also claimed that E-WOM influenced consumer purchase decision.Hennig-Thurau(17) pointed out that E-WOM's motive is how far E-WOM is useful for consumers and companies in expressing their feelings about purchased goods or services. The feeling may be either positive or negative.

Electronic word-of-mouth (eWOM) is also referred to as a medium of information exchange through communication on the internet with a specific context (11). In addition, Belch \& Belch (18) defines it as an action that provides straightforward understanding for everyone and drives them to talk about the product.

WOM information is categorized as an informal communication as it is delivered by informal sources or is not delivered on behalf of an organization or company. The forms of WOM communication can be simply passing information or giving advice about a product from family members or friends. Word of Mouth is deemed more persuasive as the information givers do not benefit from anything related to the consumer buying decision in following day(19).
There are several factors that influence E-WOM success such as Using Experience, Credibility, and Susceptibility(20). Other factors influencing E-WOM are mentioned by(21) that the message effectiveness is influential in E-WOM success. It was also pointed out by ("Electronic WOW: an exploration into the why, what and how," 2009) stating that eWOM effectiveness is affected by the individual consumer message content. It is obvious that consumer motivation determines eWOM success

(22) measures E-WOM based on the following indicators ; (1) the number of opinions written by consumers in a socaial network site known as intensity, (2) good or positive comments spread by consumers called valence of opinion and (3) comments written by consumers about product and service contents also called content. Choo et al (23) explained that good content representing consumers' satisfaction can contribute to positive E-WOM. On the other hand, (24) used source credibility, communication process and internet experience as the measurements.

Hennig-Thurau et al. (17) described that e-WOM was driven by social benefits, economic additional value, special attention to others, Venting Negative Feelings, Positive Self-Enhancement,dan Helping The Company and Advice Seeking. Along the same line, Chu and Kim (2011) stated that the motivations of EWOM in Networking Sites are Tie Strength, Homophily, Trust, Normative Influence, dan Informational Influence.

Purchase Intention is consumer behaviors related to consumers' perception and assessment on a product. This purchasing behavior refers to the ability in purchasing and evaluating product. (8) said that purchase intention tool is used to determine consumers' intention in buying a product. Purchase Intention definition according to (25) said that purchase intention factors are important factors in predicting consumers' behavior due to their subjective nature. On the other hand, Purchase Intention is a tendency in buying certain brand dan is generally based on conformity between purchasing motivation and brand characteristics (18).

In his research, (18) discovered that on-line buying can save money, time and effort so as to reduce the purchasing cost. Furthermore,(26) explained that SMEs are facing competition with on-line business requiring companies to change their business strategy in goods provisions, transaction systems and product safety and diversity offered.

Relevant to the previous statement, consumers' intention is relatively high in on line Shariah products by $(72 \%)$ overall square multiple correlation(27).

Some experts proposed the purchase intention measurement (28) as follows : (1) Likely, refers to purchase plan, (2) Definitely, refers to purchase decision (3) Propable, refers to purchasing probability. Meanwhile, (10) described different measurement on Purchase intention namely (1) Attention. Consumer and product linkages, in which case the company can draw consumers' attention by approaching the consumer to realize the existence of the product and its quality. (2) Interest. Consumer sensitivity to the product, in this stage, consumers are made interested in the product. The company strives for its products to have an appeal in consumers, so that consumers have a curiosity that can raise their interest in a product. (3) Desire. The consumer's desire to try and own the product, the consumers' curiosity towards the product is directed to the buying interest. (4) Action. Consumer action to make a purchase decision

Some research has proved the influence of E-WOM on Purchase intention and brand image (29), and it was also confirmed that eWOM affects Purchase(30).

\section{Methodology/Materials}

This research used associative method. The unit of analysis is local culinary Instagram followers in Garut, Indonesia. The total followers of this Instagram account are 60.400 .

Based on the questionnaires distributed in Intragram, the number of questionnaires filled was 76, and this number was used as the research sample. The sample was taken by using Simle random sampling technique. The analysis utilized to find out E-WOM 
factors affecting brand image is confirmatory factor analysis using SPSS. In addition, smart PLS software was used to discover the influence of E-WOM with the observed factors on consumers' purchase intention.

The indicators used to determine E-WOM fators are: intensity $(\mathrm{X} 1)$, valance of opinion(X2), dan content(X3) platform Assistance(X4), Venting Negative Feelings(X5), Concern for The Others(X6), Social Benefits(X7), Extraversion/ Positive SelfEnhancement(X8), Economic Incentives(X9), Helping The Company(X10), Advice Seeking(X11), (17, 22) These eleven factors were reduced through confirmatory factor analysis using SPSS. Moreover, The indicators used to measure purchase intention are Attention(Y1), Interest(Y2), Desire(Y3) dan (4)Action

\section{Results and Findings}

The first step in determining the E-WOM contributing factors is doing confirmatory analysis on the eleven variable analysis:intensity (X1), valance of opinion(X2), dan content(X3), platform Assistance(X4), Venting Negative Feelings(X5), Concern for
The Others(X6), Social Benefits(X7), Extraversion/Positive SelfEnhancement(X8), Economic Incentives(X9), Helping The Company(X10), dan Advice Seeking(X11)

The first phase of factor analysis is assessing appropriate variable to be taken in the next step of analysis The anlaysis was carried out through KMO and bartlett's test of Sphericity and Anti Image.

$\mathrm{KMO}$ and Barletts test value in table 1 is 0,569 with significance level 0.000; Because it is above 0.5 and the significance is far below 0.05 then the existing variables and samples can be analyzed through factor analysis.

Table 1: KMO and Bartlett's Test

\begin{tabular}{|l|l|l|}
\hline $\begin{array}{l}\text { Kaiser-Meyer-Olkin Measure of Sampling } \\
\text { Adequacy }\end{array}$ & 1408,185 \\
\hline $\begin{array}{l}\text { Bartlett's Test of } \\
\text { Sphericity }\end{array}$ & Approx. Chi-Square & 1408,185 \\
\hline & Df & 55 \\
\hline & Sig. &, 000 \\
\hline
\end{tabular}

Table 2: Anti-image Matrices

\begin{tabular}{|l|l|r|r|r|r|r|r|r|}
\hline & Content & Platform & $\begin{array}{c}\text { Negative } \\
\text { Feeling }\end{array}$ & $\begin{array}{c}\text { Concern } \\
\text { to Other }\end{array}$ & $\begin{array}{c}\text { Helping } \\
\text { Company }\end{array}$ & Intencity & Valance \\
\hline Anti-image Correlation & Content &, $728^{\text {a }}$ &, 193 &, 471 &, 065 &, 056 &,- 588 &,- 304 \\
\hline & Platform &, 193 &, $534^{\mathrm{a}}$ &, 504 &,- 808 &, 283 &, 205 &, 061 \\
\hline & $\begin{array}{l}\text { Negative } \\
\text { Feeling }\end{array}$ &, 471 &, 504 &, $690^{\mathrm{a}}$ &,- 218 &, 253 &, 352 &,- 332 \\
\hline & $\begin{array}{l}\text { Concern to } \\
\text { Other }\end{array}$ &, 065 &,- 808 &,- 218 &, $570^{\mathrm{a}}$ &,- 282 &,- 222 &,- 527 \\
\hline & $\begin{array}{l}\text { Helping } \\
\text { Company }\end{array}$ &, 056 &, 283 &, 253 &,- 282 &, $683^{\mathrm{a}}$ &, 014 &, 123 \\
\hline & Intencity &,- 588 &, 205 &, 352 &,- 222 &, 014 &, $767^{\mathrm{a}}$ &, 053 \\
\hline & Valance &,- 304 &, 061 &,- 332 &,- 527 &, 123 &, 053 &, $705^{\mathrm{a}}$ \\
\hline
\end{tabular}

a. Measures of Sampling Adequacy(MSA)

After running Anti Image test for 3 times, social benefit(X7), Extraversion(x8), Advice Seeking(X9) dan Economic Insentif(X11) variables were eliminated because the MSA is lower than 0.5. After eliminating those variables, then the KMO number rose from 0.569 to 0.66 . Table 3 shows that all variables are now higher than 0.5 . This means that these variables are ready for farther factor analysis.

Table 3: Rotated Component Matrix

\begin{tabular}{|l|r|r|}
\hline & \multicolumn{2}{|c|}{ Component } \\
\hline & $\mathbf{1}$ & \multicolumn{1}{|c|}{$\mathbf{2}$} \\
\hline Negatif Feeling &,- 948 &, 063 \\
\hline Intencity &, 947 &,- 082 \\
\hline Content &, 935 &,- 138 \\
\hline Helping Company &, 562 &,- 056 \\
\hline Concern to Other &,- 065 &, 971 \\
\hline Platform &,- 012 &, 923 \\
\hline Valance &,- 202 &, 839 \\
\hline
\end{tabular}

Based on Rotated Component Matrix result, it was discovered that Intencity(X1), Content(X3), Helping Company(X10) termasuk faktor 1, sedangkan Negatif feeling (X5), Concern to Other(X6), Platform(X4) dan Valance Negative feeling(X5) were categorized as Factor 2. Factor 1 was labeled "Product Information" and Factor 2 was labeled "Emotion".

E-WOM forming factors based on confirmatory factor analysis was named Information Product factor, this factor is a collection of factors providing product explanation and information to the costumers indicated by high intensity in raising curiosity toward the products. it was supported by(31) stating that product description is one of the effective factors in E-WOM. (32) discovered that consumers' trust was earned through the quantity and time from e-WOM information and e-WOM may affect product category. The other factor is Emotion Factor. this factor refers to the feeling perceived by the consumers for certain product. This emotion factor is a determining factor in purchase intention dan buying decision (33).
Smart PLS was then utilized to analyze the effect of E-WOM on purchase intention. PLS used Bootstraping or random multiple method. As a result, normal distribution assumption is not needed in PLS. In addition, as Bootstraping method was used, PLS does not require sample minimum size. This study took 76 samples relevant to the use of PLS. The following results were obtained through Smart PLS analysis:

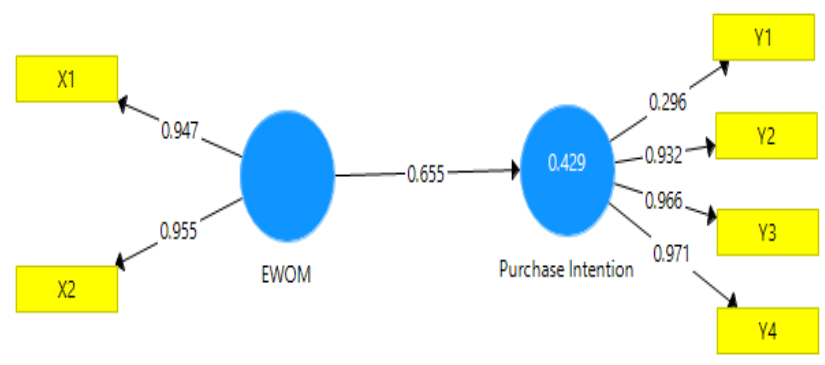

Fig 2: Result from Calculate PLS Alogaritm

The data shows that Y1 loading factor value 0.296 is lower than 0.5 . It means that $\mathrm{Y} 1$ must be eliminated from the model.

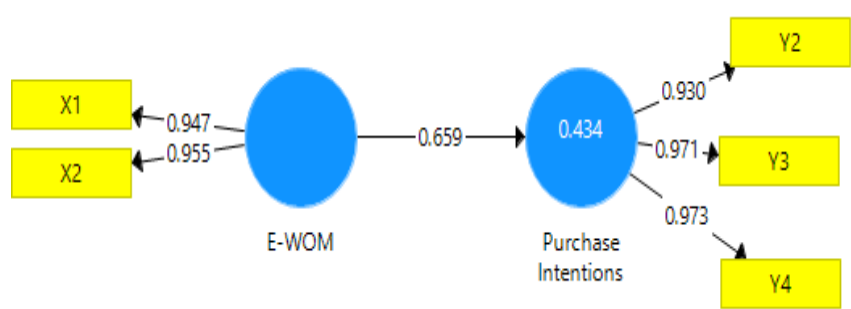

Fig 3: Result from PLS Alogaritm without Y1

Loading factor in Figure 2 is higher than 0.5. It means the indicator used in this research is valid or has fulfilled the convergent validity. Another method used to find out the discriminant validity 
is by referring to square root of average variance extracted (AVE) The accepted value is higher than 0.5 The AVE values in this research are 0.904 and 0.918 . Both are higher than 0.5 as the accepted AVE value.

Reliability test was carried out by finding composite reliability value from indicator block measuring construct. The result showed that the satisfying value must be higher than 0.7. The obtained values are 0.898 and 0.958 . Both are higher than 0.7. The reliability tes was also supported by Cronbach Alpha resulting 0.894 and 0.955 . The accepted score must be higher than 0.6. From the table it is obvious that the Cronbach Alpha for all constructs are higher than 0.6

The first inner model test is R-square, the result is 0.434 . It confirmed that E-WOM was able to describe Purchase Intention Variance by 43.4 percent. The following model was obtained from Bootstrapping result:

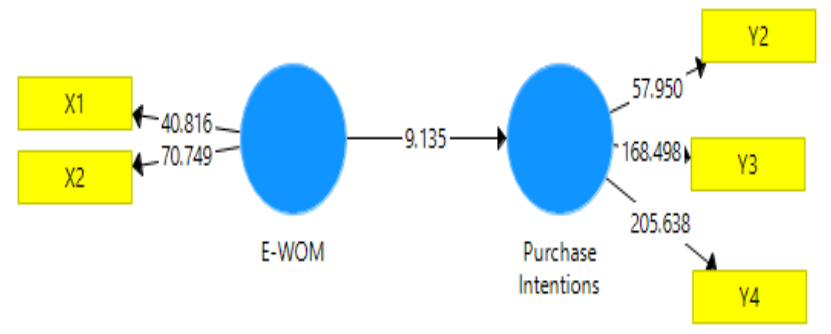

Fig 4: Model from Bootstrapping

Table 5: (Bootsrapping Run)

\begin{tabular}{|l|l|l|l|l|}
\hline & $\begin{array}{l}\text { Origional } \\
\text { Sampel }\end{array}$ & $\begin{array}{l}\text { Sample } \\
\text { Mean }\end{array}$ & $\begin{array}{l}\text { Standar } \\
\text { Devation }\end{array}$ & T observed \\
\hline EW->PI & 0,659 & 0,649 & 0.072 & 9,135 \\
\hline
\end{tabular}

The table proves that EWOM has significant correlation with $\mathrm{T}$ obseved by 9.135 (> 1.66) The direction of EWOM and purchase intention correlation is positive by 0.659 . Therefore, the hypothesi of this research stating that EWOM signficantly affect purchase intention is accepted.

In Jajanan Garut Instagram, E-WOM has greatly affected in determining purchase intention, this purchase intention is motivated by the information and emotion. This is supported by the very high role of internet technology in Indonesia, especially in Garut regency. In addition, the high motivation in using social media has also affected purchase intention (34). Some research has also confirmed the effect of E-WOM on purchase intention as in $(16,35$, 36).

\section{Conclusion}

Based on the result and findings, it can be concluded that: Based on Rotated Component Matrix, the contributing factors in electronic word of mouth are Intencity(X1), Content(X3), Helping Company (X10) as factor 1, and Negatif feeling (X5), Concern to Other(X6), Platform (X4) and Valance Negative feeling (X5) as factor 2. Factor 1 was labeled "Product Information" factor and Factor 2 was labeled "Emotion" factor.

Based on the data analysis, it was confirmed that EWOM has a significant correlation with Purcahse intention and that the hypothesis stating that "EWOM significantly influence purchase intention" is accepted Therefore, the result has proven that in "Jajanan Garut" Instagram account, E-WOM has siginificant influence in purchase intention, this is because both the information and emotional feelings motivates purchase intention.

\section{References}

[1] Ramadhilla Maghfira U, Donald Crestofel L. Development of Competitivenes Model for Small - Medium. the Indonesian Journal of Business Administration. 2013;2(11):1309-18.

[2] BPS. Social And Economic Survei. Indonesia: 2017

[3] GAPMMI. Potensi Industri Mamin Terbuka. Jawa Pos. 2014.
[4] Akyüz A. Determinant Factors Influencing eWOM. Mediterranean Journal of Social Sciences. 2013;4(11):159-66.

[5] Lu X, Li Y, Zhang Z, Rai B. Consumer Learning Embedded in Electronic Word of Mouth. Journal of Electronic Commerce Research. 2014;15(4):300-16.

[6] Lancastre A, Lages LF. The relationship between buyer and a B2B e-marketplace: Cooperation determinants in an electronic market context. Industrial Marketing Management. 2006;35(6):774-89.

[7] Pemda. Profil Ekonomi Kabupaten Garut. 2015.

[8] Kotler P, Keller KL. Marketing Management2009. 329-31 p.

[9] Kaijasilta N. The Conceptualization of Electronic Word-of-Mouth (EWOM) and Company Practices to Monitor, Encourage, and Commit to EWOM - a Service Industry Perspective: Aalto University School of Business; 2013.

[10] Kotler PdKKL. Marketing Management. 14 ed. New Jersey: Pearson; 2012. 546- $\mathrm{p}$.

[11]Yulianto E. LAKIP Dinas Koperasi dan UKM Kabupaten Garut. Garut: 2015.

[12] Sweeney JC, Soutar GN, Tim M. Exploring the Message Characteristics of Word-of-Mouth: A Study in a Services Context 2008:1-7.

[13]Bass F. A new product growth for model consumer durables* '. Management Sciences. 1967(August):215-27.

[14] Thoumrungroje A. The Influence of Social Media Intensity and EWOM on Conspicuous Consumption. Procedia - Social and Behavioral Sciences. 2014;148(November 2012):7-15.

[15]Wang YC. A study on the influence of electronic word of mouth and the image of gastronomy tourism on the intentions of tourists visiting Macau. Tourism. 2015;63(1):67-80.

[16]Lamba B, Manav A. A Study on Influence of eWOM: Consumer Buying Behavior. THE INTERNATIONAL JOURNAL OF BUSINESS \& MANAGEMENT. 2016;4(1):246-51.

[17]Hennig-Thurau T, Gwinner KP, Walsh G, Gremler DD. Electronic word-of-mouth via consumer-opinion platforms: what motivates consumers to articulate themselves on the internet? Journal of interactive marketing. 2004;18(1):38-52.

[18]Belch GE, Belch MA. Advertising and Promotion an Integrated Marketing Communications. 6 ed. New York: Prentice Hall; 2003.

[19] Schiffman LG, Kanuk LL. Consumer behaviour 8 th ed. NY: Prentice-Hall Inc. 2004.

[20]Park C, Wang Y, Yao Y, Kang YR. Factors Influencing eWOM Effects: Using Experience, Credibility, and Susceptibility. International Journal of Social Science and Humanity. 2011;1(1):74-9.

[21] Kim S, Martinez B, McClure CS, Kim SH. E-WOM Intentions towards Social Media Messages eWOM Intentions toward. Atlantic Marketing Journal. 2016;5(1):137-54.

[22] Goyette I, Ricard L, Bergeron J. e-WOM Scale : Word-of-Mouth Measurement Scale for e-Services Context *. 2010;23:5-23.

[23] Choo TC, Jamil B, Daud AAA. Electronic Word of Mouth ( eWOM ) on restaurants in Sarawak. 2016;13(13):249139-49.

[24]López M, Sicilia M. Determinants of E-WOM influence: The role of consumers' internet experience. Journal of Theoretical and Applied Electronic Commerce Research. 2014;9(1):28-43.

[25] Ajzen I. Attitude and Behavior: Milton Keynes: Open University Press; 1998.

[26] Tallud FF. Online Buying Behaviour of SMEs. 2014:3(1):19-26.

[27] Imhmed Mohmed AS, Binti Azizan N, Zalisham Jali M. Investigating Customer's Intention to Purchase Online Based on Sharia Perspective. Research in Electronic Commerce Frontiers. 2016;3:7-17.

[28]Till BDBM. The Match-up Hypothesis: Physical Attractiveness, Expertise, and the Role of Fit on Brand Attitude, Purchase Intentions, and Brand Beliefs. Journal of Advertising. 2000;3:1-13.

[29]Ruhamak MD, Budi R. Pengaruh Word of Mouth Terhadap Purchase Intention Melalui Brand Image Pada Lembaga Kursus Bahasa Inggris Dynamic English Course Pare. Jurnal Ekonomi Universitas Kediri. 2016;1(2):188-204.

[30]Chang L-y, Lee Y-J, Huang CLC-L. The influence of E-Word-OfMouth on the Consumer's Purchase Decision: a Case of Body Care Products. Journal of Global Business Management. 2012;6:1-7.

[31]Cheung CMK, Thadani DR. The State of Electronic Word-OfMouth Research: A Literature Analysis. PACIS 2010 Proceedings. 2010:151-.

[32]Xiaorong F, Bin Z, Qinghong X, Liuli X, Yu C. Impact of Quantity and Timeliness of EWOM Information on Consumer's Online Purchase Intention under C2C Environment. Asian Journal of Business Research. 2011;1(2):37-52. 
[33] Achar C, So J, Agrawal N, Duhachek A. What we feel and why we buy: The influence of emotions on consumer decision-making. Current Opinion in Psychology. 2016;10:166-70.

[34] Kim S, Martinez B, McClure C, Kim SH. eWOM Intentions toward Social Media Messages. Atlantic Marketing Journal. 2016;5(1):137-55.

[35]Lerrthaitrakul W, Panjakajornsak V. The Impact of Electronic Word-of-Mouth Factors on Consumers' Buying Decision-Making
Processes in the Low Cost Carriers: A Conceptual Framework. International Journal of Trade, Economics and Finance. 2014;5(2):142-6.

[36] Rizqia CD, Hudrasyah H. The Effect of Electronic Word-Of-Mouth on Customer Purchase Intention ( Case Study : Bandung Culinary Instagram Account ). 2015;3(3). 